Article

\title{
Salient Ballot Measures and the Millennial Vote
}

\author{
Scott J. LaCombe * and Courtney Juelich
}

Department of Political Science, University of lowa, lowa City, IA 52240, USA; E-Mails: scott-lacombe@uiowa.edu (S.J.L.), courtney-juelich@uiowa.edu (C.J.)

* Corresponding author

Submitted: 15 December 2018 | Accepted: 12 March 2019 | Published: 27 June 2019

\begin{abstract}
We explore the relationship between ballot measures on issues salient to Millennials and their turnout in presidential and midterm elections. Both scholars and observers in the media have worried about decreasing levels of citizen participation, particularly among young voters. We demonstrate that one way to engage Millennials into traditional forms of political participation is through ballot measures that focus on issues salient to their generation (marijuana liberalization and higher education reform). We show that not only do these measures increase Millennial voting, but they erase difference in turnout levels between Millennials and older generations. This effect is primarily concentrated in low-turnout contexts such as midterm elections, indicating that these measures may be playing a similar mobilization role in midterm elections as presidential campaigns do in turnout out low-propensity voters.
\end{abstract}

\section{Keywords}

ballot measures; direct democracy; generation; Millennials; political behavior; turnout; voting

Issue

This article is part of the issue "The Politics, Promise and Peril of Direct Democracy", edited by Todd Donovan (Western Washington University, USA).

(C) 2019 by the authors; licensee Cogitatio (Lisbon, Portugal). This article is licensed under a Creative Commons Attribution 4.0 International License (CC BY).

\section{Introduction}

Scholars have documented a significant decrease in turnout across the US and other Western democracies over the past half century (Franklin, 2004; McDonald, 2018). Millennial voters (those born between 1982 and 1996) are no exception to this trend. Millennial voter turnout barely reached 50 percent in the 2016 presidential election, compared to 70 percent for Baby Boomers (Fry, 2016). Some activists want to use high profile ballot measures on issues such as marijuana legalization to increase youth voter turnout, similar to how activists on the right attempted to use same-sex marriage bans to turn out social conservatives in the 2004 Presidential election (Campbell \& Monson, 2008).

We test if Millennial salient measures increase Millennial voter turnout in both presidential and midterm elections. We argue that Millennial-oriented ballot measures provide a path for engaging these voters, who appear to be disenchanted with politics due to years of per- ceived political dysfunction (Foa \& Mounk, 2016). Millennials have a cynical view of politics as the issues most important to them scarcely make it onto a party's platform (Lawless \& Fox, 2015). Understanding what drives turnout among the largest cohort of potential voters is fundamental to understanding democracy in the US. This is especially important as Millennials are now the largest living generation. Understanding their political behavior and opinions, and how they compare to those of older generations, is vital to understanding the trajectory of participation in American politics.

We argue that ballot measures increase Millennial turnout in midterm and presidential elections most when the proposals are focused on issues particularly salient to them. We focus on higher education reform and marijuana liberalization because of their unique level of interest in both issues. Millennials began enrolling in college at the same time as the cost of college tuition, fees, and room and board skyrocketed. They hold the highest amounts of student debt of any gener- 
ation. Millennials' experience with higher education is uniquely marked by a hyper-concern for the cost of and access to higher education institutions (Rouse \& Ross, 2018; Taylor \& Keeter, 2010). Millennials are also the most supportive of marijuana legalization. In 2016, 71 percent of Millennials said that marijuana use should be legal. Just 33 percent of the silent generation, 56 percent of Baby Boomers, and 57 percent of Generation X respondents say marijuana should be made legal (Geiger, 2016). Their distinct opinions on marijuana and unique experience with higher education make both policy areas highly salient for Millennial voters relative to the rest of the population. These two issues should mobilize Millennials more than other generations ${ }^{1}$.

Over the past sixteen years, measures on marijuana liberalization and higher education reform have been placed on the ballot and voted on across the country. We collect a unique dataset of state ballot measures on marijuana liberalization and higher education reform. We pair these data with the Current Population Survey from 2002-2016 to model voter turnout. We find that Millennials are more likely to vote when there are more measures on issues salient to them. The increases in turnout erase differences between Millennials and other generations. When Millennials can vote on issues that are important to them, they are just as likely to vote as the rest of the population.

\section{Millennial and Their Political Behavior}

Much of the research on age or youth turnout has focused on life-cycle effects and maturation, which is the idea that at different points, or ages, in one's life political participation becomes more important, such as having a family or nearing retirement (Converse, 1972; Plutzer, 2002). However, many have found that the young turnout to vote at the lowest rates not due to life-stage effects but because of a variety of generational factors, like low social capital, apathy towards the government, and lack of interest in politics overall (Putnam, 2000; Wolfinger \& Rosenstone, 1980). Most simply, there are group-wide trends of lower participation, and the gap is not closed as one ages, thus indicating a cohort effect rather than an effect of aging.

Research in comparative politics on voter turnout has moved beyond life-cycle effects to evaluate generational differences in political behavior (Inglehart \& Welzel, 2005). This research emphasizes the distinct socioeconomic context that each cohort of voters' face. Currently, the youngest voters in Western countries vote at lower rates than previous generations when they were the same age (Campbell, Converse, Miller, \& Stokes, 1980; Franklin, 2004; Miller, Shanks, \& Shapiro, 1996). Failure to account for cohort-effects in political behavior leads researchers to omit the shared experiences and opinions of a generation and overestimate the effect of age. Incorporating generational effects into models of voter turnout provides us with a way to separate the persistent effect of generation and the temporary effect of age.

Scholars over the past 50 years have conceptualized age-related cohorts in the US into generations. In demographic research, like that done by Pew Research Center, current generations are categorized as, the Silent Generation, Baby Boomers, Generation X, the Millennials, and Generation Z. Those belonging to the Silent Generation are the oldest Americans. They are classified as those born before 1946. Baby Boomers, the next oldest group are those born between 1946 and 1964. Generation X are those born between 1965 and 1980. Millennials are those who were born in 1981 to 1996, and Generation Z are those born after 1996 (Taylor, 2016).

Political differences between generations have been well documented (Putnam, 2000; Robinson \& Jackson, 2001). Inter-generational differences extend beyond beliefs and include differences in political behavior (Dalton, 2015). Millennials are less likely to vote, donate money, and contact legislators than all previous generations (Franklin, 2004; Henn, Weinstein, \& Forrest, 2005; Klecka, 1971). Dalton (2008) attributes low levels of Millennial turnout to dissatisfaction with the political elites and the economic system. Dalton also documents a generational inclination towards non-traditional, or engaged, forms of political participation, like protesting, consumer activism, and volunteering with non-profits in their communities.

The 2008 Presidential election sparked increased interest in understanding what drives youth political behavior due to their uncharacteristically high turnout, interest, and activism in President Obama's presidential campaign. Obama's success in mobilizing young voters led researchers to seek to explain why youth turnout was so high in this election but not in others. Some of these scholars found that the youth are not participating in politics as much as other generational cohorts because of perceptions of the political system being unresponsive or corrupt. Lawless and Fox (2015) argue the mean-spirited and dysfunctional nature of American politics has led the youth to doubt the ability of elected officials and the government to be an effective entity for promoting positive change. Obama's message of hope and change may have cut through this perception. As demonstrated by the Obama and Sanders campaigns, when candidates or campaigns respond to young people's disillusionment, we observe relatively high levels of young voter turnout. Although younger generations, including Millennials, are not engaging in politics as much as earlier generations, some conditions lead to spikes in their participation. In this study, we explore if direct democracy can counteract Millennial disillusionment with the political system to increase their turnout.

\section{Direct Democracy and Voting}

Direct democracy in American states, particularly the ballot initiative, has been thoroughly studied for decades

\footnotetext{
${ }^{1}$ All estimations will compare turnout of Millennials to turnout of Generation X, Baby Boomers, and the Silent Generation.
} 
both for its effect on state policy outputs (Gerber, 1996; Matsusaka, 2001) and the public (Smith, 2001; Tolbert, Bowen, \& Donovan, 2009; Tolbert, McNeal, \& Smith, 2003). Every state has some form of direct democracy, be it the initiative process, referendums, or both, although there is significant institutional variation in whether they have the initiative process and the ease of qualifying measures on the ballot (Bowler \& Donovan, 2004). While ballot measures are used to accomplish specific policies goals, their usage changes the election environment for states, and has been found to produce externalities in voter participation and attitudes.

There are two principle explanations for how direct democracy increases voter turnout. One is that direct democratic institutions have a long term educative effect, increasing voter interest in their government and in being active democratic participants (Bowler \& Donovan, 2002; Tolbert \& Smith, 2005; Tolbert et al., 2003). Progressive activists hoped the ballot initiative would foster the citizenry in becoming a new branch of government that could be active in the policy making process. Activists hoped that over time, as the institutions of ballot initiatives and referendum matured, voters would become more engaged in the political process because they were given more influence in policy making. Researchers have also found that previous initiative use increases turnout (Bowler \& Donovan, 2002; Hero \& Tolbert, 2004). Tolbert, Grummel and Smith (2001) show an increase in voter turnout in initiative states regardless of the number of measures on the ballot. Based on these findings, a key understanding of direct democracy is that it seems to empower voters even if it is not being used in that specific election.

The second explanation argues that having a procedure for direct democracy is insufficient for driving turnout. Rather, turnout effects are observed when measures qualify to be on the ballot. There is large variation in the types of direct democracy (initiatives, popular referendum, veto referendum, etc.) as well as the requirements for placing measures on the ballot, leading to large variation in ballot measure usage in the states (Bowler \& Donovan, 2004). Once on the ballot, direct democracy increases turnout by mobilizing individuals in support of specific issues (Biggers, 2011; Childers \& Binder, 2012; Tolbert et al., 2009). This effect is particularly large when ballot measures are salient to the public (Dyck \& Seabrook, 2010). The most notable examples of this phenomena were the same-sex marriage bans on the ballot in the 2004 general election. These measures increased turnout among Evangelicals and other conservative Christians relative to the rest of the population (Campbell \& Monson, 2008; Smith, DeSantis, \& Kassel, 2006). These voters felt disproportionately passionate about the issue, and the mobilization from the measures comparatively increased their turnout. This supports Nicholson's (2003) argument that direct democracy will have the strongest effect when voters are aware of ballot measures. Holding all else constant, ballot mea- sure usage increases turnout above and beyond the effect of having a direct democratic process.

Like most research on ballot measures, turnout effects must be contextualized. Direct democracy typically increases turnout in low-turnout contexts, such as midterm elections (Schlozman \& Yohai, 2008). Presidential elections have significantly higher levels of voter turnout (A. Campbell, 1960; J. E. Campbell, 1987), so any mobilization effects from ballot measures may be washed out by the overwhelming turnout effects of presidential campaigns. Research on the educative effects of direct democracy (and more specifically, ballot initiatives) has been more mixed (Seabrook, Dyck, \& Lascher, 2015). Political scientists have generally found support for more ballot measures being associated with higher voter turnout, particularly in conditions where turnout is historically lower (midterm elections, for example). Higher turnout may be a result of both the long-term and short-term effects of direct democracy.

\section{Direct Democracy and Millennial Voting}

We believe that an understudied area of direct democracy's mobilization effect is how it interacts differently with each living generation. We argue that when measures are salient to Millennials, they will vote at relatively high rates. First, the empowering effect of ballot measures has been shown to be concentrated most among low-propensity voters and in low-turnout environments (Schlozman \& Yohai, 2008; Tolbert \& Smith, 2005). Highly engaged voters will likely vote with or without measures on the ballot. However, the decreased turnout in midterm elections creates the opportunity for interest groups to mobilize and persuade non-regular voters who are passionate about an issue to participate. Even a small increase in turnout from low-propensity voters can lead to a proposal being adopted or struck down (Anzia, 2011, 2013). Most Millennials are non-habituated voters, but potential voters with strong and serious concern for salient issues like higher education reform and marijuana liberalization.

The turnout effects should be primarily focused on voters who are on the cusp of voting but need some additional stimulus to turnout. Historically, there is a population of low propensity voters that turnout in competitive presidential elections (A. Campbell, 1960), but turnout at much lower rates in midterm elections when the president they voted for is not on the ballot (J. E. Campbell, 1987). Compared to other ages, younger voters are less likely to turnout to vote, especially in midterm elections (Campbell et al., 1980; Wolfinger \& Rosenstone, 1980). We have also observed generational declines in political participation, including in voting, across all of the Western industrialized democratic nations (Franklin, 2004). Turnout in midterm and presidential elections varies greatly, with much lower turnout in midterm elections where information and excitement are lower. Millennials make an ideal candidate for researching the effects 
of direct democracy on turnout because they are a large pool of potential voters who decide to stay home during midterm elections, but that could potentially be mobilized under the right conditions.

An additional reason to study Millennials is because they are relatively new to politics and may lack the influence of older generations in the policy-making process. There is a substantial literature that finds that not all groups are treated the same by policy-makers (Boushey, 2016). We argue that the record levels of disenchantment with the democratic process among Millennial voters (Foa \& Mounk, 2016) is a product of a lack of policies salient to their preferences. These disengaged voters feel that traditional policy-making institutions do not respond to their preferences, thus they feel that voting is less important. Ballot measures provide a way to empower Millennials to actively pass legislation that corresponds with their policy preferences. A similar dynamic has been observed in off-year elections voters with a stake in the election outcome, such as members of an interest group that is affected by election results, vote in disproportionately high levels (Anzia, 2011, 2013). While Millennials are not organized as a unified interest group, we follow a similar logic by arguing that Millennials will be more likely to vote when elections incorporate issues important to their generation. Two such issues are higher education reform and marijuana liberalization. We identify these issues as salient to Millennials for several reasons.

Millennials are the most educated generation in American history in terms of earning college degrees (Taylor, 2016). Millennials also reached college age at the time where the rate of inflation for a higher education rapidly increased. As of December 2016, the average American student left university with over $\$ 30,000$ in student loan debt (National Center for Education Statistics, 2017). This number, even when adjusted for inflation, has risen by over 530 percent since the 1960s. Unlike other generations, Millennials cite the rising cost of education as one of the most important issues facing them today (Rouse \& Ross, 2018). For Millennials, a politician's stance on higher education funding and debt forgiveness is a top policy issue when considering who to vote for, unlike non-Millennial voters (Rouse \& Ross, 2018).

Second, we consider marijuana liberalization as a salient issue because Millennials have distinct attitudes about marijuana. Millennials support both medical and recreational marijuana legalization at higher levels than any other generation (Hargit \& Geiger, 2018). In 2018, 74 percent of Millennials approved of legalization, compared to 54 percent of Boomers. Generation X approval is in the middle of the two generations, with 63 percent supporting legalization. Generational differences in attitudes on marijuana are much larger than differences by education and race (Hargit \& Geiger, 2018). Hargit and Geiger (2018) conclude that the legalization of marijuana connects to deeper values held by the Millennial generation, such as tolerance and support for ethnic and racial justice.
Although Millennials have distinct views on these two topic areas, they are similar to other generations on a number of issues. For comparison Millennials hold similar opinions to other generations on issues like abortion, Social Security, and Medicare. In 2017, the 62 percent of Millennials said abortion should be legal in all or most cases, compared to 59 percent of Generation Xers, 53 percent of Baby Boomers, and 48 percent of the Silent Generation (Doherty, Kiley, \& O'Hea, 2018). For Social Security the difference across those who oppose cuts in Social Security benefits is also moderate. 61 percent of Millennials, 67 percent of Generation X, 69 percent of Baby Boomers, and 74 percent of the Silent Generation believe benefits should not be reduced (Taylor, 2016). Finally, overwhelming majorities of each generation support Medicare. There is only a seven percent range between the low end of support (Baby Boomers, 85 percent) and the high end (Silent Generation, 92 percent). Millennials and Generation $X$ fall between the two with support at 87 percent and 89 percent respectively (Taylor, 2016). In summary, Millennials are not systematically different than other generations on every issue; higher education reform and marijuana liberalization are two policy areas that are particularly distinct to the Millennial generation, especially compared to other generations.

The usage of Millennial salient ballot measures over the last two decades provides the context for testing a few hypotheses. First, we predict that the number of Millennial salient measures will increase Millennial turnout relative to the rest of the population. Just as ballot measures emphasizing issues important to evangelical voters boosted their turnout (Campbell \& Monson, 2008), we expect measures on higher education and marijuana to have the same effect for Millennial voters.

Hypothesis 1. Millennial turnout is expected to increase as the number of Millennial measures increases.

Additionally, the effect should be more pronounced in midterm environments than presidential elections. Historically, there is a sharp drop in voter turnout from presidential to midterm elections (A. Campbell, 1960; J. E. Campbell, 1987; McDonald, 2018). In midterms, we expect measures to have a larger role because there is a large pool of voters who vote in presidential elections, but not in midterms. Midterm elections create a strategic opportunity for interest groups to mobilize bases of support to pass preferred policies (Anzia, 2011, 2013). We argue that Millennial measures will provide the stimulus to increase turnout among Millennials that regularly vote in presidential elections, but that do not in Midterms. Salient measures will have less of an effect in presidential years because these elections are more salient to the average voter, and presidential campaigns have extensive mobilization efforts that may supersede the effect of ballot measures. 
Hypothesis 2. The turnout effects of Millennial salient measures on Millennial turnout will be larger in midterm than presidential elections.

\section{Data and Methods}

We use voter turnout data from the Current Population Survey (CPS) Voting and Registration Supplement to test our theory. This survey includes 700,000 individual turnout records from 2002-2016. This telephone survey has been conducted every two years in November and includes US citizens age eighteen or older. The survey is drawn from a stratified sample to create a representative sample of adult citizens.

We choose 2002 as the start year for our sample because it is the first year Millennials make up a substantial percentage of the CPS data: approximately 7 percent of the sample ${ }^{2}$. The percentage of the CPS that is Millennial grows each year as more Millennials become voting age. Millennials constitute 28 percent of respondents in the 2016 CPS $^{3}$. We combine the CPS with a unique data set of the number of Millennial salient ballot measures from 2002-2016 using the National Conference of State Legislatures' (2016) Statewide Ballot Measures Database. We identify any initiative or referendum that liberalizes marijuana laws (both recreational and medicinal) or aims to make higher education more affordable or accessible. We identify 1,599 statewide ballot measures (either ini- tiative or referendum) during general elections in this time period, with 90 being coded as Millennial-salient, composing just over 6 percent of the sample. 55 percent of the Millennial-salient measures were on higher education reform, and 45 percent on marijuana liberalization. We did not code measures as Millennial-salient if they focused on making marijuana laws more restrictive or if they were about higher education but did not emphasize affordability or availability. The average state had .225 Millennial salient measures in each election, meaning there was one measure roughly every four elections per state in our sample. The sample has a high of five measures in a state in a single election, and a low of zero.

Like other research in direct democracy (Bowler \& Donovan, 2004), we find that not all states are equal in their usage of Millennial-salient measures. Rhode Island and New Mexico had ten Millennial measures between 2002-2016, followed by Arizona (eight). Seven states had three measures, six had two measures, seven had one measure, and twenty-three states had no salient measures in the sample. Figure 1 shows the total number of salient measures in our data by state.

Our dependent variable is voter turnout. We interact our key independent variable, Millennial Measures, with a measure of generation. We use Pew Research Center's age range for each living generation. Table 1 shows the distribution of generations. Boomers make up the largest cohort in the sample, followed by Generation X. Millen-

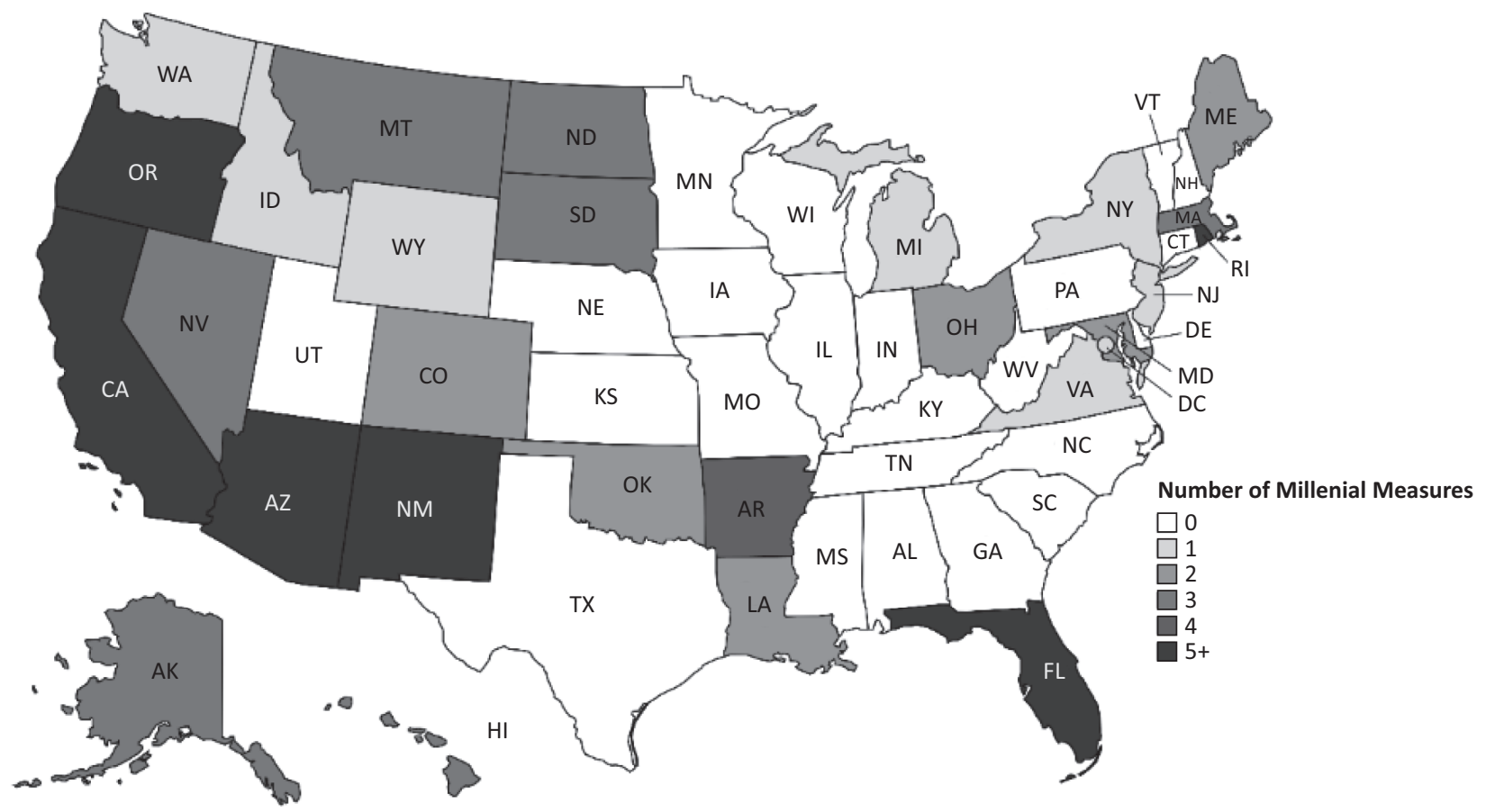

Figure 1. Number of Millennial salient measures. Source: National Conference of State Legislatures (2016).

\footnotetext{
2 While the oldest of Millennials reached voting age in 2000, they did not make up a sufficiently large proportion of the sample for state level analysis.

${ }^{3}$ Beginning in 2016, those born in 1997 and 1998 (Generation X) were eligible to vote. They make up .2 percent of the sample and are not large enough to include as a separate generation, so they are omitted from the sample.
} 
Table 1. Distribution of Generations. Source: U.S. Census Bureau (2002-2016).

\begin{tabular}{ll}
\hline Generation & Sample Size \\
\hline Millennial & $148,170(19.7 \%)$ \\
Gen X & $202,243(26.8 \%)$ \\
Boomer & $259,663(34.4 \%)$ \\
Silent & $143,229(19 \%)$ \\
\hline Total & 753,308 \\
\hline
\end{tabular}

nials and the Silent generation are roughly the same size. We also use a binary indicator for Millennials in a parallel set of analyses. These two measures of generation provide insights for how Millennials compare to other cohorts as well as how they are different from the rest of the population overall. In both sets of models, we include age to control for lifetime effects. Including age allows us to distinguish between lifetime effects (aging, retirement, etc.) versus generational effects that emerge from the collective socialization of each generation. Specifically, life cycle effects are the idea that one's habits and opinions change over the course of their lives, and from their maturation from being children, to young adults, to adults, and to retirees. Alternatively, cohorts are a group of individuals who have experienced the same event within the same time interval (Ryder, 1965). One way to better parse out age or maturation effects from cohort effects is to include a control for age, and use binary indicator for generations (O'Brien, Stockard, \& Isaacson, 1999).

We estimate a multilevel logistic regression to model individual voter turnout, with random intercepts for state and fixed effects for year to account for state-level differences in turnout and turnout effects of individual election years. We estimate four models for each generational indicator; a pooled model with no interaction, a pooled model interacting generation with Millennial measures, the same interaction model but of only respondents in initiative states, and finally the interaction model of respondents living in a state with at least one Millennial measure in that year. We choose initiative states as a subsample because these states may have a historical legacy of direct democracy that makes them systematically different than non-initiative states. They chose to adopt the initiative process, which potentially indicates these states respond differently to voters. The final set of models will compare midterm and presidential election turnout. These models will subsample the data with both generational measures in just mid-term and just presidential elections. This approach will test if salient ballot measures can activate low propensity voters that are activated by presidential campaigns but do not typically vote in midterm elections. These models will identify contexts in which Millennial measures have a greater effect on turnout, and which ones they do not.

Because the effects of direct democracy have been shown to be conditional on electoral context, we include an indicator for presidential election years, and identify states that have competitive statewide elections for pres- ident, US Senate, and governor. To further model competitiveness, we include a measure for the total spending per capita of all US Senate, House, and presidential campaigns in a state. We also use Li, Pomantell, and Schraufnagel (2018) Cost of Voting index, which is an index of 33 state election and registration laws that measure the level of difficulty for voters to vote. Higher values indicate a higher cost of voting. These contextual variables help isolate the influence of ballot measures on voting from other sources of increased voter turnout. Finally, we include individual demographic controls, including income, age, race, and education. Table 2 shows the descriptive statistics for each variable and Table 3 provides a brief description of variables.

\section{Results}

Table 4 models turnout using the categorical measure of generation. The last three models interact each generation with the number of Millennial salient measures. The first model shows differences across generations, but without the interaction. The reference category is the Baby Boomer generation. Figure 2 compares the predicted probability of voting for each generation based on the results in model 4 of Table 4 . Without accounting for the potential moderating effect of Millennial salient ballot measures, Millennials are eight to ten percentage points less likely to vote than Baby Boomers or members of the Silent Generation, while they vote at slightly lower rates than Generation X voters. This supports the existing literature that even when controlling for age, education, income, and other factors that influence voter turnout, there are differences in turnout between generations (Franklin, 2004).

Model 2 shows the results for all elections in the sample. Millennials are less likely to vote than Baby Boomers when the number of Millennial measures is zero. Generation $X$ voters are also less likely to vote than Boomers, and the Silent Generation is more likely to vote, holding all else constant and the number of Millennial measures at zero. Increasing the number of Millennial salient measures has no effect on Generation X or Silent Generation voters compared to Boomers but increases turnout among Millennials. This model supports our hypothesis that Millennial salient measures will increase turnout specifically among Millennials. If there are five Millennial measures in an election, turnout differences between Millennials and Boomers disappear. Figure 3 shows the 
Table 2. Summary statistics.

\begin{tabular}{|c|c|c|c|c|}
\hline Variable & Mean & Sd & Min & Max \\
\hline Vote & 0.622 & 0.485 & 0.000 & 1.000 \\
\hline Mil Measures & 0.244 & 0.524 & 0.000 & 5.000 \\
\hline Millennial & 0.171 & 0.376 & 0.000 & 1.000 \\
\hline Male & 0.474 & 0.499 & 0.000 & 1.000 \\
\hline Age & 47.846 & 17.695 & 18.000 & 85.000 \\
\hline Initiative State & 0.482 & 0.500 & 0.000 & 1.000 \\
\hline Income & 9.815 & 4.885 & 0.000 & 16.000 \\
\hline Missing Income & 0.092 & 0.289 & 0.000 & 1.000 \\
\hline Education & 3.219 & 1.546 & 1.000 & 6.000 \\
\hline Total Spending per Capita (Standardized) & -0.000 & 1.000 & -0.588 & 7.026 \\
\hline Competitive Gubernatorial Election & 0.269 & 0.443 & 0.000 & 1.000 \\
\hline Competitive Senate Election & 0.164 & 0.370 & 0.000 & 1.000 \\
\hline Competitive Presidential Election & 0.175 & 0.380 & 0.000 & 1.000 \\
\hline Presidential Election & 0.496 & 0.500 & 0.000 & 1.000 \\
\hline Cost of Voting Index & 0.000 & 1.000 & -3.979 & 1.841 \\
\hline
\end{tabular}

Sources: US Census Bureau (2002-2016), National Conference of State Legislatures (2016) and The Campaign Finance Institute (2019).

Table 3. Description of variables.

\begin{tabular}{|c|c|}
\hline Variable & Description \\
\hline Vote & Binary Indicator for Vote/No Vote \\
\hline Millennial & Binary Indicator Millennial Generation \\
\hline Generation & $\begin{array}{l}\text { Categorical Measure of Millennial, Generation X, Boomers, and Silent Generation, } \\
\text { generated by year of birth }\end{array}$ \\
\hline Millennial Measures & $\begin{array}{l}\text { Number of Ballot Measures on marijuana liberalization or higher education reform in } \\
\text { a state in the general election }\end{array}$ \\
\hline Age & Age of respondent \\
\hline Male & Binary indicator for male/not male \\
\hline Hispanic & Binary indicator for Hispanic \\
\hline Black & Binary indicator for Black \\
\hline Initiative & Binary indicator for an initiative state \\
\hline Income & Categorical measure of income (CPS) from 1-16, grouping individuals by ranges of income \\
\hline Missing Income & $\begin{array}{l}\text { Binary indicator for respondents with no information on their income. This was used to } \\
\text { preserve cases and not omit any systematic difference in the sample between those } \\
\text { that gave their income versus those that refused }\end{array}$ \\
\hline Education & 6 category measure of education ranging from less than high school to advanced degree \\
\hline $\begin{array}{l}\text { Federal Campaign } \\
\text { Spending }\end{array}$ & $\begin{array}{l}\text { Amount of money spent by major party federal campaigns (House, Senate, and President) } \\
\text { in an election year in a state per capita. (This variable has been standardized) }\end{array}$ \\
\hline $\begin{array}{l}\text { Competitive } \\
\text { Gubernatorial Race }\end{array}$ & $\begin{array}{l}\text { Binary indicator-Campaign Finance Institute's measure of competitive gubernatorial } \\
\text { elections }\end{array}$ \\
\hline Competitive Senate Race & Binary indicator for senate race where margin of victory was less than 10 percent \\
\hline $\begin{array}{l}\text { Competitive Presidential } \\
\text { Race }\end{array}$ & Binary indicator for presidential race where margin of victory was less than 10 percent \\
\hline Presidential Election & Binary indicator for presidential election year \\
\hline Cost of Voting & $\begin{array}{l}\text { Lee et al's (2018) measure of the cost of voting using a measure of } 30 \text { different electoral } \\
\text { laws in the states such as voter ID, registration regulations, and other laws }\end{array}$ \\
\hline
\end{tabular}


Table 4. Generational model of turnout using total count of ballot measures in an election.

\begin{tabular}{|c|c|c|c|c|}
\hline & All States & All States & Initiative States & States with Any Measures \\
\hline Millennial & $\begin{array}{c}-0.3954^{*} \\
(0.0198)\end{array}$ & $\begin{array}{c}-0.3514^{*} \\
(0.0184)\end{array}$ & $\begin{array}{c}-0.4068^{*} \\
(0.0306)\end{array}$ & $\begin{array}{c}-0.3943^{*} \\
(0.0249)\end{array}$ \\
\hline Generation X & $\begin{array}{c}-0.2888^{*} \\
(0.0131)\end{array}$ & $\begin{array}{c}-0.2818^{*} \\
(0.0115)\end{array}$ & $\begin{array}{c}-0.2858^{*} \\
(0.0214)\end{array}$ & $\begin{array}{c}-0.2722 * \\
(0.0173)\end{array}$ \\
\hline Silent/Greatest & $\begin{array}{c}0.0869 * \\
(0.0154)\end{array}$ & $\begin{array}{c}0.1124^{*} \\
(0.0136)\end{array}$ & $\begin{array}{c}0.0961^{*} \\
(0.0252)\end{array}$ & $\begin{array}{c}0.0675^{*} \\
(0.0201)\end{array}$ \\
\hline Total Measures & $\begin{array}{c}-0.0008 \\
(0.0017)\end{array}$ & $\begin{array}{c}0.0035^{*} \\
(0.0014)\end{array}$ & $\begin{array}{c}-0.0025 \\
(0.0022)\end{array}$ & $\begin{array}{c}-0.0013 \\
(0.0019)\end{array}$ \\
\hline Millennial \# Total Measures & $\begin{array}{c}0.0124^{*} \\
(0.0021)\end{array}$ & & $\begin{array}{c}0.0196 * \\
(0.0028)\end{array}$ & $\begin{array}{c}0.0140 * \\
(0.0025)\end{array}$ \\
\hline Generation X \# Total Measures & $\begin{array}{c}0.0020 \\
(0.0018)\end{array}$ & & $\begin{array}{c}0.0041 \\
(0.0025)\end{array}$ & $\begin{array}{c}0.0011 \\
(0.0022)\end{array}$ \\
\hline Silent \# Total Measures & $\begin{array}{c}0.0076 * \\
(0.0021)\end{array}$ & & $\begin{array}{c}0.0070 * \\
(0.0029)\end{array}$ & $\begin{array}{c}0.0084^{*} \\
(0.0025)\end{array}$ \\
\hline Age & $\begin{array}{c}0.0277^{*} \\
(0.0005)\end{array}$ & $\begin{array}{c}0.0277^{*} \\
(0.0005)\end{array}$ & $\begin{array}{c}0.0288^{*} \\
(0.0008)\end{array}$ & $\begin{array}{c}0.0282 * \\
(0.0006)\end{array}$ \\
\hline Male & $\begin{array}{r}-0.1118^{*} \\
(0.0057)\end{array}$ & $\begin{array}{r}-0.1117^{*} \\
(0.0057)\end{array}$ & $\begin{array}{r}-0.1270 * \\
(0.0082)\end{array}$ & $\begin{array}{r}-0.1170 * \\
(0.0067)\end{array}$ \\
\hline Hispanic & $\begin{array}{r}-0.1679 * \\
(0.0118)\end{array}$ & $\begin{array}{r}-0.1662 * \\
(0.0118)\end{array}$ & $\begin{array}{r}-0.1547^{*} \\
(0.0160)\end{array}$ & $\begin{array}{r}-0.1321 * \\
(0.0138)\end{array}$ \\
\hline Black & $\begin{array}{c}0.4814^{*} \\
(0.0104)\end{array}$ & $\begin{array}{c}0.4813^{*} \\
(0.0104)\end{array}$ & $\begin{array}{c}0.4407^{*} \\
(0.0170)\end{array}$ & $\begin{array}{c}0.4550^{*} \\
(0.0126)\end{array}$ \\
\hline Initiative State & $\begin{array}{c}0.1149 * \\
(0.0542)\end{array}$ & $\begin{array}{c}0.1142 * \\
(0.0541)\end{array}$ & & $\begin{array}{c}0.1059 \\
(0.0551)\end{array}$ \\
\hline Income & $\begin{array}{c}0.0870 * \\
(0.0008)\end{array}$ & $\begin{array}{c}0.0870 * \\
(0.0008)\end{array}$ & $\begin{array}{c}0.0866 * \\
(0.0012)\end{array}$ & $\begin{array}{c}0.0862^{*} \\
(0.0010)\end{array}$ \\
\hline Missing Income & $\begin{array}{c}0.7687^{*} \\
(0.0138)\end{array}$ & $\begin{array}{c}0.7687^{*} \\
(0.0138)\end{array}$ & $\begin{array}{c}0.7515^{*} \\
(0.0204)\end{array}$ & $\begin{array}{c}0.7319 * \\
(0.0165)\end{array}$ \\
\hline Education & $\begin{array}{c}0.3938^{*} \\
(0.0022)\end{array}$ & $\begin{array}{c}0.3937^{*} \\
(0.0022)\end{array}$ & $\begin{array}{c}0.3845^{*} \\
(0.0032)\end{array}$ & $\begin{array}{c}0.3909 * \\
(0.0025)\end{array}$ \\
\hline Federal Campaign Spending & $\begin{array}{c}0.0133^{*} \\
(0.0044)\end{array}$ & $\begin{array}{c}0.0131 * \\
(0.0044)\end{array}$ & $\begin{array}{c}-0.0213^{*} \\
(0.0060)\end{array}$ & $\begin{array}{c}0.0090 \\
(0.0049)\end{array}$ \\
\hline Competitive Gub Race & $\begin{array}{c}0.0785^{*} \\
(0.0076)\end{array}$ & $\begin{array}{c}0.0780 * \\
(0.0076)\end{array}$ & $\begin{array}{c}0.1045^{*} \\
(0.0106)\end{array}$ & $\begin{array}{c}0.0947^{*} \\
(0.0091)\end{array}$ \\
\hline Competitive Senate Race & $\begin{array}{c}0.1052^{*} \\
(0.0088)\end{array}$ & $\begin{array}{c}0.1049 * \\
(0.0088)\end{array}$ & $\begin{array}{c}0.1474^{*} \\
(0.0142)\end{array}$ & $\begin{array}{c}0.1172 * \\
(0.0105)\end{array}$ \\
\hline Competitive Presidential Election & $\begin{array}{c}0.1203^{*} \\
(0.0107)\end{array}$ & $\begin{array}{c}0.1202 * \\
(0.0107)\end{array}$ & $\begin{array}{c}0.0735^{*} \\
(0.0159)\end{array}$ & $\begin{array}{c}0.1008^{*} \\
(0.0133)\end{array}$ \\
\hline Presidential Year & $\begin{array}{c}0.7404^{*} \\
(0.0151)\end{array}$ & $\begin{array}{c}0.7409^{*} \\
(0.0151)\end{array}$ & $\begin{array}{c}0.8141^{*} \\
(0.0217)\end{array}$ & $\begin{array}{c}0.7424^{*} \\
(0.0184)\end{array}$ \\
\hline Cost of Voting & $\begin{array}{r}-0.0457^{*} \\
(0.0058)\end{array}$ & $\begin{array}{c}-0.0471^{*} \\
(0.0058)\end{array}$ & $\begin{array}{c}-0.0433^{*} \\
(0.0077)\end{array}$ & $\begin{array}{r}-0.0490 * \\
(0.0068)\end{array}$ \\
\hline Constant & $\begin{array}{c}-3.2652 * \\
(0.0480)\end{array}$ & $\begin{array}{c}-3.2801 * \\
(0.0478)\end{array}$ & $\begin{array}{c}-3.2043^{*} \\
(0.0583)\end{array}$ & $\begin{array}{r}-3.2677^{*} \\
(0.0526)\end{array}$ \\
\hline $\operatorname{var}\left(\beta_{\text {State }}\right)$ & $\begin{array}{c}0.0359 * \\
(0.0073)\end{array}$ & $\begin{array}{c}0.0359 * \\
(0.0073)\end{array}$ & $\begin{array}{c}0.0340 * \\
(0.0100)\end{array}$ & $\begin{array}{c}0.0363 * \\
(0.0075)\end{array}$ \\
\hline Observations & 668,352 & 668,352 & 321,885 & 478,033 \\
\hline
\end{tabular}

Notes: ${ }^{*} \mathrm{p}<.05$. All models include random intercepts for State and fixed effects for year.

marginal effect of Millennial measures on turnout by generation. While these measures have no effect on other generations, they increase Millennial turnout by one percent for each additional measure.
Models 3 and 4 compare the contextual effects of salient measures by the ballot measure context. In both models, Millennial measures have a mediated effect on turnout for Millennials but not for other generations. 


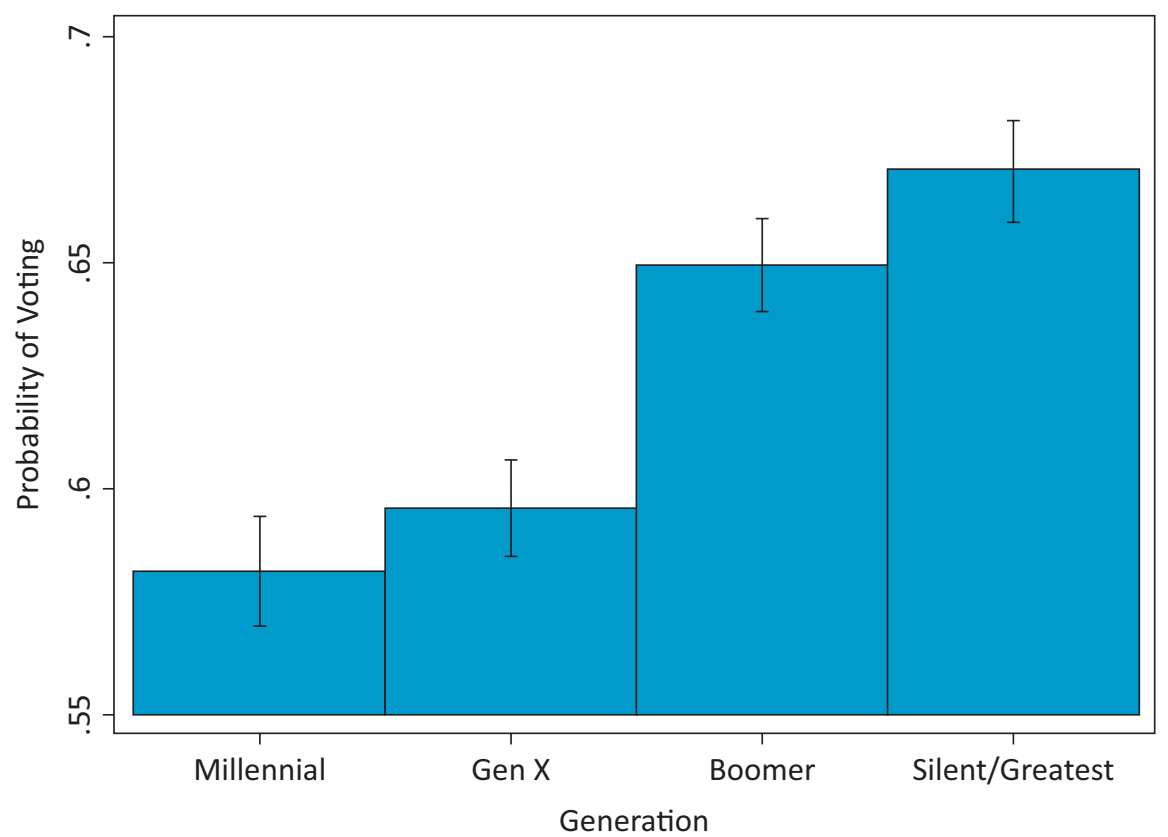

Figure 2. Probability of voting by generation. Probabilities shown are population-averaged probabilities.

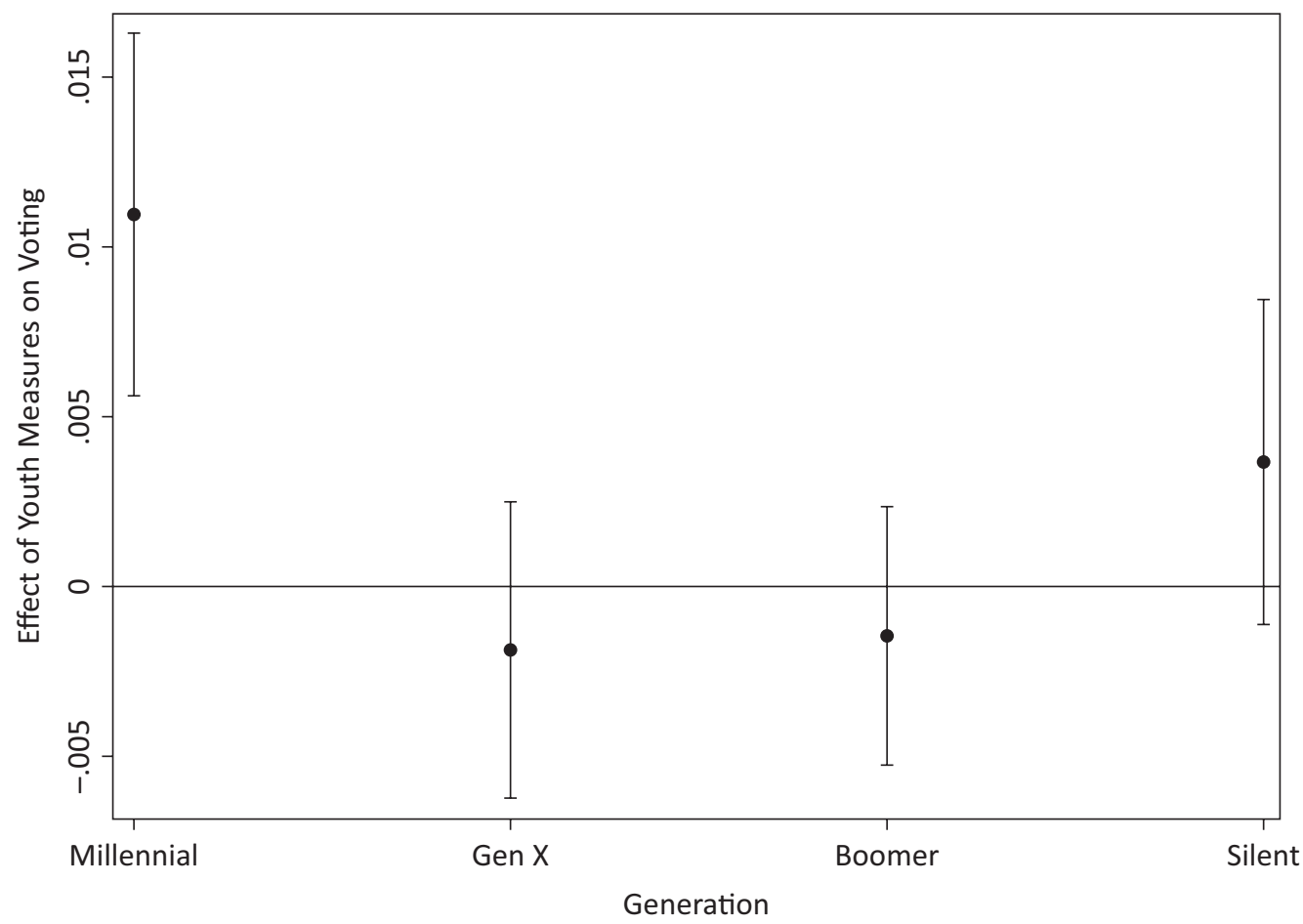

Figure 3. Marginal effect of Millennial measures on turnout by generation. Marginal effects shown are populationaveraged.

Note that when the number of measures is zero, there are still persistent and substantively large turnout gaps between generations. The fourth model shows that the relationship is not being driven by just whether states have any measures salient to Millennials, but that the number of measures is also important. Even when isolated to just states that have measures on the ballot in an election, additional Millennial measures increase turnout among Millennials.
Other contextual variables are largely congruent with our expectations. Initiative states have somewhat higher turnout, and competitive gubernatorial, senatorial, and presidential elections in a state all increase voter turnout. As the cost of voting increases, citizens become less likely to vote. In the pooled model, increased federal campaign spending per capita is significantly related to increased voter turnout. Additionally, presidential elections see higher turnout than non-presidential elections. 
Table 6 compares the effect of salient ballot measures in midterm and presidential elections. As can be seen, Millennial measures have no generational effects in presidential elections, but have a positive and significant effect on Millennial turnout in midterm elections. Salient measures appear to be activating Millennials in midterm elections, taking a similar role to presidential campaigns in presidential election years.

\section{Millennials versus the Rest of the Population}

Table 5 is the same specification as Table 4 but uses a binary measure to compare Millennials to the rest of the population. In the model with no interaction, Millennials do not vote at significantly different rates than the rest of the population after controlling for demographic factors. This is likely because Generation X voter turnout is much closer to Millennial turnout than Boomer or Silent Generation voters. Yet despite similarities in baseline levels of turnout between Millennials and other voters when there are no Millennial measures on the ballot, only Millennials appear to be affected by measures on marijuana liberalization or higher education reform. When the interaction is included, Millennials are less likely to vote than the rest of the population when there are no salient measures. The difference in turnout is small enough that

Table 5. Binary Millennial measure model of turnout using total count of ballot measures.

\begin{tabular}{|c|c|c|c|c|}
\hline & All States & All States & Initiative States & States with Any Measures \\
\hline \multirow[t]{2}{*}{ Millennial } & $-0.0421^{*}$ & -0.0064 & $-0.0546^{*}$ & $-0.0548^{*}$ \\
\hline & $(0.0117)$ & $(0.0098)$ & $(0.0191)$ & $(0.0157)$ \\
\hline \multirow[t]{2}{*}{ Total Measures } & 0.0017 & $0.0036 *$ & 0.0006 & 0.0011 \\
\hline & $(0.0014)$ & $(0.0014)$ & $(0.0018)$ & $(0.0015)$ \\
\hline \multirow[t]{2}{*}{ Millennial \# Total Measures } & $0.0101^{*}$ & & $0.0165^{*}$ & $0.0117^{*}$ \\
\hline & $(0.0018)$ & & $(0.0025)$ & $(0.0022)$ \\
\hline \multirow[t]{2}{*}{ Age } & $0.0370 *$ & $0.0370 *$ & $0.0382 *$ & 0.0370* \\
\hline & $(0.0002)$ & $(0.0002)$ & $(0.0003)$ & $(0.0003)$ \\
\hline \multirow[t]{2}{*}{ Male } & $-0.1097^{*}$ & $-0.1096^{*}$ & $-0.1253^{*}$ & $-0.1150 *$ \\
\hline & $(0.0057)$ & $(0.0057)$ & $(0.0082)$ & $(0.0067)$ \\
\hline \multirow[t]{2}{*}{ Hispanic } & $-0.1699 *$ & $-0.1680^{*}$ & $-0.1565^{*}$ & $-0.1346^{*}$ \\
\hline & $(0.0118)$ & $(0.0118)$ & $(0.0160)$ & $(0.0138)$ \\
\hline \multirow[t]{2}{*}{ Black } & $0.4833^{*}$ & $0.4831^{*}$ & $0.4416^{*}$ & $0.4566^{*}$ \\
\hline & $(0.0104)$ & $(0.0104)$ & $(0.0170)$ & $(0.0126)$ \\
\hline \multirow[t]{2}{*}{ Initiative State } & $0.1145^{*}$ & $0.1136 *$ & & 0.1058 \\
\hline & $(0.0542)$ & $(0.0542)$ & & $(0.0552)$ \\
\hline \multirow[t]{2}{*}{ Income } & $0.0880^{*}$ & 0.0879* & $0.0872 *$ & $0.0870^{*}$ \\
\hline & $(0.0008)$ & $(0.0008)$ & $(0.0012)$ & $(0.0010)$ \\
\hline \multirow[t]{2}{*}{ Missing Income } & $0.7777^{*}$ & $0.7778 *$ & $0.7582 *$ & $0.7400 *$ \\
\hline & $(0.0138)$ & $(0.0138)$ & $(0.0204)$ & $(0.0165)$ \\
\hline \multirow[t]{2}{*}{ Education } & $0.3918^{*}$ & $0.3917^{*}$ & $0.3825^{*}$ & $0.3891^{*}$ \\
\hline & $(0.0022)$ & $(0.0022)$ & $(0.0031)$ & $(0.0025)$ \\
\hline \multirow[t]{2}{*}{ Federal Campaign Spending } & $0.0134^{*}$ & $0.0132 *$ & $-0.0212^{*}$ & 0.0093 \\
\hline & $(0.0044)$ & $(0.0044)$ & $(0.0060)$ & $(0.0049)$ \\
\hline \multirow[t]{2}{*}{ Competitive Gub Race } & $0.0788 *$ & $0.0780 *$ & $0.1048^{*}$ & $0.0949 *$ \\
\hline & $(0.0076)$ & $(0.0076)$ & $(0.0106)$ & $(0.0091)$ \\
\hline \multirow[t]{2}{*}{ Competitive Senate Race } & 0.1049* & $0.1045^{*}$ & $0.1463^{*}$ & $0.1164^{*}$ \\
\hline & $(0.0088)$ & $(0.0088)$ & $(0.0142)$ & $(0.0105)$ \\
\hline \multirow[t]{2}{*}{ Competitive Presidential Election } & $0.1205^{*}$ & $0.1204 *$ & $0.0737^{*}$ & $0.1014^{*}$ \\
\hline & $(0.0107)$ & $(0.0107)$ & $(0.0159)$ & $(0.0133)$ \\
\hline \multirow[t]{2}{*}{ Presidential Year } & $0.6258^{*}$ & $0.6264^{*}$ & $0.6994^{*}$ & $0.6327^{*}$ \\
\hline & $(0.0138)$ & $(0.0138)$ & $(0.0198)$ & $(0.0169)$ \\
\hline \multirow[t]{2}{*}{ Cost of Voting } & $-0.0456^{*}$ & $-0.0470 *$ & $-0.0429 *$ & $-0.0485^{*}$ \\
\hline & $(0.0058)$ & $(0.0058)$ & $(0.0077)$ & $(0.0068)$ \\
\hline \multirow[t]{2}{*}{ Constant } & $-3.7763^{*}$ & $-3.7818^{*}$ & $-3.7110^{*}$ & $-3.7562 *$ \\
\hline & $(0.0419)$ & $(0.0419)$ & $(0.0471)$ & $(0.0447)$ \\
\hline \multirow[t]{2}{*}{$\operatorname{var}\left(\beta_{\text {State }}\right)$} & $0.0360 *$ & $0.0360 *$ & $0.0341^{*}$ & $0.0364 *$ \\
\hline & $(0.0073)$ & $(0.0073)$ & $(0.0100)$ & $(0.0075)$ \\
\hline Observations & 668,352 & 668,352 & 321,885 & 478,033 \\
\hline
\end{tabular}

Notes: $* p<.05$. All models include random intercepts for State and fixed effects for year. 
one Millennial measure is enough to result in Millennials being more likely to vote than the rest of the population.

Figure 4 shows the predicted probabilities for model 2 of Table 5 . When there are no measures on the ballot, Millennials vote at basically the same rate as the rest of the population, controlling for other factors. As the number of measures increases, so does Millennial turnout while the rest of the population barely changes and moves in a slightly negative direction. Millennial turnout increases by roughly one percentage point for each additional salient measure on the ballot. When states have five measures on the ballot, there is roughly a six percent difference in turnout between Millennials and the rest of the population. In models 3 and 4 , there is no significant difference between Millennial turnout and the rest of the population when there are no Millennial measures, but Millennial measures still increase Millennial turnout.

Controlling for other factors, Millennials are more likely to vote than the rest of the population in a variety of contexts as the number of measures increases. The contextual electoral variables largely have the same effect as in Table 3. Voters in initiative states with competitive elections, a low cost of voting, and with a presidential election are more likely to vote. Table 6 compares the models in midterm and presidential elections using both the generational and binary measures to identify Millennials. Again, Millennial measures do not have a significant interactive effect with generation in presidential elections but does in midterm elections. Millennial measures still have a mediating effect after controlling for context, but the effect is concentrated in midterm elections.

\section{Discussion and Conclusion}

These findings have several important implications. First, we have demonstrated that there are real differences between generations in political participation. Controlling for a variety of factors (including age and electoral competitiveness), Millennials are less likely to vote than other generations. We find consistent generational declines in voter turnout, which could have long lasting implications for American democracy as an increasing number of citizens stop participating.

We have also shown that the electoral context has a different effect depending on the generation. For all sets of models, Millennials are significantly more likely to vote when there are more measures on the ballot salient to them. The effect cancels out any generational differences between Millennials and other cohorts. Millennials are the only age group affected by these measures as we observe no significant increases or decreases in turnout in other generations. They are not completely disengaged from the political process but will be more likely to participate when the system is responding to their preferences. These findings provide more support for arguments that much of Bernie Sanders' success with youth voters was due to his emphasis on issues important to Millennials, particularly his support for tuition free university education. When elections include discussion of issues salient to Millennials, they turnout at higher rates.

Substantively the effect size of increased Millennial ballot measures is between a one and two percentage point increase in turnout for Millennials for each additional salient ballot measure. Given that the 2016

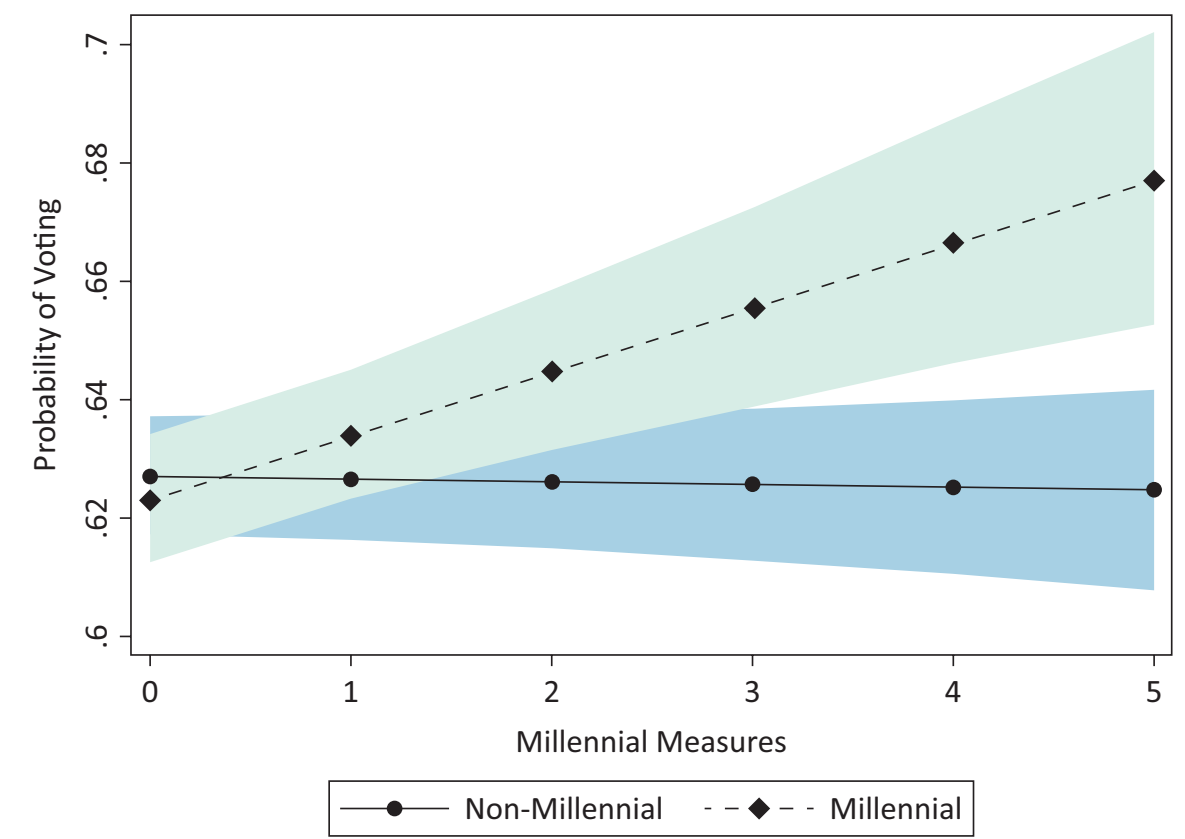

Figure 4. Predicted probability of voting- Millennials vs rest of population. Probabilities shown are population-averaged probabilities. 
Table 6. Comparing presidential and mid-term elections.

\begin{tabular}{|c|c|c|c|c|}
\hline & $\begin{array}{l}\text { Presidential- } \\
\text { Generational }\end{array}$ & $\begin{array}{l}\text { Mid-Term- } \\
\text { Generations }\end{array}$ & $\begin{array}{c}\text { Presidential-Binary } \\
\text { Measure }\end{array}$ & $\begin{array}{c}\text { Mid-Term-Binary } \\
\text { Measure }\end{array}$ \\
\hline Millennial & $\begin{array}{r}-0.3194 * \\
(0.0279)\end{array}$ & $\begin{array}{r}-0.5110 * \\
(0.0253)\end{array}$ & $\begin{array}{l}-0.0064 \\
(0.0149)\end{array}$ & $\begin{array}{r}-0.1511 * \\
(0.0152)\end{array}$ \\
\hline Gen X & $\begin{array}{r}-0.2520 * \\
(0.0179)\end{array}$ & $\begin{array}{r}-0.3089 * \\
(0.0158)\end{array}$ & & \\
\hline Silent & $\begin{array}{r}0.0997 * \\
(0.0212)\end{array}$ & $\begin{array}{r}0.0826 * \\
(0.0186)\end{array}$ & & \\
\hline Millennial Measures & $\begin{array}{c}-0.0167 \\
(0.0138)\end{array}$ & $\begin{array}{c}-0.0113 \\
(0.0148)\end{array}$ & $\begin{array}{l}-0.0018 \\
(0.0091)\end{array}$ & $\begin{array}{c}-0.0049 \\
(0.0111)\end{array}$ \\
\hline Millennial \# Millennial Measures & $\begin{array}{c}0.0109 \\
(0.0207)\end{array}$ & $\begin{array}{r}0.1182 * \\
(0.0258)\end{array}$ & $\begin{array}{c}0.0132 \\
(0.0181)\end{array}$ & $\begin{array}{r}0.1124 * \\
(0.0238)\end{array}$ \\
\hline Gen X \# Millennial Measures & $\begin{array}{c}0.0053 \\
(0.0194)\end{array}$ & $\begin{array}{l}-0.0113 \\
(0.0202)\end{array}$ & & \\
\hline Silent \# Millennial Measures & $\begin{array}{l}-0.0065 \\
(0.0215)\end{array}$ & $\begin{array}{c}0.0419 \\
(0.0221)\end{array}$ & & \\
\hline Age & $\begin{array}{c}0.0216 * \\
(0.0008)\end{array}$ & $\begin{array}{r}0.0323 * \\
(0.0007)\end{array}$ & $\begin{array}{r}0.0299 * \\
(0.0003)\end{array}$ & $\begin{array}{r}0.0417 * \\
(0.0003)\end{array}$ \\
\hline Male & $\begin{array}{r}-0.1981 * \\
(0.0085)\end{array}$ & $\begin{array}{r}-0.0422 * \\
(0.0077)\end{array}$ & $\begin{array}{r}-0.1971 * \\
(0.0085)\end{array}$ & $\begin{array}{r}-0.0391 * \\
(0.0077)\end{array}$ \\
\hline Hispanic & $\begin{array}{r}-0.1622 * \\
(0.0153)\end{array}$ & $\begin{array}{r}-0.1897 * \\
(0.0177)\end{array}$ & $\begin{array}{r}-0.1261 * \\
(0.0153)\end{array}$ & $\begin{array}{r}-0.1922 * \\
(0.0177)\end{array}$ \\
\hline Black & $\begin{array}{r}0.6175 * \\
(0.0157)\end{array}$ & $\begin{array}{r}0.3790 * \\
(0.0139)\end{array}$ & $\begin{array}{r}0.6200 * \\
(0.0158)\end{array}$ & $\begin{array}{r}0.3822 * \\
(0.0139)\end{array}$ \\
\hline Income & $\begin{array}{r}0.0899 * \\
(0.0012)\end{array}$ & $\begin{array}{r}0.0842 * \\
(0.0012)\end{array}$ & $\begin{array}{r}0.0910 * \\
(0.0012)\end{array}$ & $\begin{array}{r}0.0859 * \\
(0.0012)\end{array}$ \\
\hline Missing Income & $\begin{array}{r}0.7590 * \\
(0.0201)\end{array}$ & $\begin{array}{r}0.7641 * \\
(0.0190)\end{array}$ & $\begin{array}{l}0.7666 * \\
(0.0200)\end{array}$ & $\begin{array}{r}0.7787 * \\
(0.0190)\end{array}$ \\
\hline Education & $\begin{array}{r}0.4564 * \\
(0.0034)\end{array}$ & $\begin{array}{r}0.3520 * \\
(0.0028)\end{array}$ & $\begin{array}{r}0.4560 * \\
(0.0034)\end{array}$ & $\begin{array}{r}0.3500 * \\
(0.0028)\end{array}$ \\
\hline Cong Campaign Spending & $\begin{array}{c}0.0114 \\
(0.0063)\end{array}$ & $\begin{array}{r}0.0392 * \\
(0.0042)\end{array}$ & $\begin{array}{l}0.0157 * \\
(0.0065)\end{array}$ & $\begin{array}{r}0.0394 * \\
(0.0042)\end{array}$ \\
\hline Competitive Gub Race & $\begin{array}{c}0.0179 \\
(0.0164)\end{array}$ & $\begin{array}{r}0.0961 * \\
(0.0090)\end{array}$ & $\begin{array}{r}-0.0341 * \\
(0.0168)\end{array}$ & $\begin{array}{r}0.0959 * \\
(0.0091)\end{array}$ \\
\hline Competitive Senate Race & $\begin{array}{r}0.0301 * \\
(0.0142)\end{array}$ & $\begin{array}{l}0.1514 * \\
(0.0119)\end{array}$ & $\begin{array}{c}-0.0083 \\
(0.0151)\end{array}$ & $\begin{array}{r}0.1509 * \\
(0.0118)\end{array}$ \\
\hline Competitive Pres Election & $\begin{array}{l}0.0635 * \\
(0.0109)\end{array}$ & & $\begin{array}{r}0.0384 * \\
(0.0144)\end{array}$ & \\
\hline Initiative State & $\begin{array}{r}0.4262 * \\
(0.0139)\end{array}$ & $\begin{array}{r}0.2016 * \\
(0.0093)\end{array}$ & $\begin{array}{r}0.2143 * \\
(0.0135)\end{array}$ & $\begin{array}{r}0.2010 * \\
(0.0092)\end{array}$ \\
\hline Cost of Voting & $\begin{array}{c}-0.0004 \\
(0.0055)\end{array}$ & $\begin{array}{r}-0.0888 * \\
(0.0046)\end{array}$ & $\begin{array}{r}-0.0268 * \\
(0.0053)\end{array}$ & $\begin{array}{r}-0.0892 * \\
(0.0047)\end{array}$ \\
\hline Constant & $\begin{array}{r}-2.3079 * \\
(0.0446)\end{array}$ & $\begin{array}{r}-3.3161 * \\
(0.0390)\end{array}$ & $\begin{array}{r}-2.6720 * \\
(0.0303)\end{array}$ & $\begin{array}{r}-3.8476 * \\
(0.0246)\end{array}$ \\
\hline $\operatorname{var}\left(\beta_{\text {State }}\right)$ & $\begin{array}{c}2.0725 e+08^{*} \\
(10679863.1088)\end{array}$ & $\begin{array}{l}86564960.66 * \\
(3920093.018)\end{array}$ & $\begin{array}{c}1.9222 \mathrm{e}+08^{*} \\
(13332112.51)\end{array}$ & $\begin{array}{l}86624295.89 * \\
(3854348.487)\end{array}$ \\
\hline Observations & 329,368 & 338,984 & 329,368 & 338,984 \\
\hline
\end{tabular}

Notes: All models include random intercepts for State and fixed effects for year. ${ }^{*}$ indicates $p<.05$.

presidential election was decided by roughly 100,000 voters in Pennsylvania, Wisconsin, and Michigan, and many razor thin margins in US House and Senate elections in 2018, a two-percentage point increase in Millennial turnout could have a tremendous effect on elec- tion results. A two-percentage point increase in Millennial turnout translates into 1.5 million more voters participating in elections.

Secondly, our findings support existing research that direct democracy has a context-dependent effect on 
voter turnout, and that the effect is largest in low turnout contexts. We find that the turnout effect is mostly concentrated in midterm contests, which historically have lower levels of turnout, particularly for Millennial voters. It appears that these salient measures act in a similar way as presidential campaigns in mobilizing Millennial voters. Differences between Millennial and other generations are largest when there is no presidential election or salient measures. That being said, not all measures are created equal. The turnout effect of ballot measures is concentrated on issues that are salient to a particular voter group. Just as Smith et al. (2006) and Campbell and Monson (2008) find that same sex marriage bans increased conservative Christian turnout in the 2004 presidential election, we find that when measures focus on issues salient to Millennials, their turnout increases.

Lastly, we want to emphasize the implication of these findings on American political behavior over time. The surge in turnout in the 2018 midterm non-withstanding (McDonald, 2018), there are fears that disillusionment with the political system is leading to increasingly low turnout elections, particularly in midterms. A key point of emphasis for activists is getting low propensity voters to participate. Salient ballot measures may be a way to not only accomplish policy goals, but to also engage populations that turnout at lower levels. Repeated elections with mobilizing measures could create millions of habitual voters (Plutzer, 2002) who will be more likely to participate in future elections even without the stimulus of salient measures.

\section{Acknowledgments}

We would like to thank Professors Caroline Tolbert and Frederick Boehmke for their valuable insights and assistance in developing this project.

\section{Conflict of Interests}

The authors declare no conflict of interests.

\section{References}

Anzia, S. F. (2011). Election timing and the electoral influence of interest groups. The Journal of Politics, 73(2), 412-427.

Anzia, S. F. (2013). Timing and turnout: How off-cycle elections favor organized groups. Chicago, IL: University of Chicago Press.

Biggers, D. R. (2011). When ballot issues matter: Social issue ballot measures and their impact on turnout. Political Behavior, 33(1), 3-25.

Boushey, G. (2016). Targeted for diffusion? How the use and acceptance of stereotypes shape the diffusion of criminal justice policy innovations in the American states. American Political Science Review, 110(1), 198-214.

Bowler, S., \& Donovan, T. (2002). Democracy, institutions and attitudes about citizen influence on government. British Journal of Political Science, 32(2), 371-390.

Bowler, S., \& Donovan, T. (2004). Measuring the effect of direct democracy on state policy: Not all initiatives are created equal. State Politics \& Policy Quarterly, 4(3), 345-363.

Campbell, A. (1960). Surge and decline: A study of electoral change. Public Opinion Quarterly, 24(3), 397-418.

Campbell, J. E. (1987) The revised theory of surge and decline. American Journal of Political Science, 31(4), 965-979.

Campbell, D. E., \& Monson, J. Q. (2008). The religion card: Gay marriage and the 2004 presidential election. Public Opinion Quarterly, 72(3), 399-419.

Campbell, A., Converse, P. H., Miller, W. E., \& Stokes, D. E. (1980). The American voter. Chicago, IL: University of Chicago Press.

Childers, M., \& Binder, M. (2012). Engaged by the initiative? How the use of citizen initiatives increases voter turnout. Political Research Quarterly, 65(1), 93-103.

Converse, P. E. (1972). Change in the American electorate. In The human meaning of social change (pp. 263-337). New York, NY: Russell Sage Foundation.

Dalton, R. J. (2008). Citizenship norms and the expansion of political participation. Political Studies, 56(1), 76-98.

Dalton, R. J. (2015). The good citizen: How a younger generation is reshaping American politics. Washington, DC: CQ Press.

Doherty, C., Kiley, J., \& O'Hea, O. (2018). The generation gap in American politics. Pew Research Center. Retrieved from https://www.people-press.org/2018/ 03/01/the-generation-gap-in-american-politics

Dyck, J. J., \& Seabrook, N. R. (2010). Mobilized by direct democracy: Short-term versus long-term effects and the geography of turnout in ballot measure elections. Social Science Quarterly, 91(1), 188-208.

Franklin, M. N. (2004). Voter turnout and the dynamics of electoral competition in established democracies since 1945. Cambridge: Cambridge University Press.

Fry, R. (2016). Millennials approach Baby Boomers as America's largest generation in the electorate. Pew Research Center. Retrieved from www.pewresearch. org

Foa, R. S., \& Mounk, Y. (2016). The democratic disconnect. Journal of Democracy, 27(3), 5-17.

Geiger, A. W. (2016). Support increases for marijuana legalization. Pew Research Center. Retrieved from https://www.pewresearch.org/fact-tank/2016/10/ 12/support-for-marijuana-legalization-continuesto-rise

Gerber, E. R. (1996). Legislative response to the threat of popular initiatives. American Journal of Political Science, 40(1), 99-128.

Hargit, H., \& Geiger, A. W. (2018). About six-in-ten Americans support marijuana legalization. Pew Research Center. Retrieved from https://www.pewresearch. 
org/fact-tank/2018/10/08/americans-supportmarijuana-legalization

Henn, M., Weinstein, M., \& Forrest, S. (2005). Uninterested youth? Young people's attitudes towards party politics in Britain. Political Studies, 53(3), 556-578.

Hero, R. E., \& Tolbert, C. J. (2004). Minority voices and citizen attitudes about government responsiveness in the American states: Do social and institutional context matter? British Journal of Political Science, 34(1), 109-121.

Inglehart, R., \& Welzel, C. (2005). Modernization, cultural change, and democracy: The human development sequence. Cambridge: Cambridge University Press.

Klecka, W. R. (1971). Applying political generations to the study of political behavior: A cohort analysis. Public Opinion Quarterly, 35(3), 358-373.

Lawless, J. L., \& Fox, R. L. (2015). Running from office: Why young Americans are turned off to politics. Oxford: Oxford University Press.

Matsusaka, J. (2001). Problems with a methodology used to evaluate the voter initiative. The Journal of Politics, 63(4), 1250-1256.

McDonald, M. (2018). National turnout rates, 1787-2016. United States elections project. Retrieved from http://www.electproject.org

Miller, W. E., Shanks, J. M., \& Shapiro, R. Y. (1996). The new American voter. Cambridge, MA: Harvard University Press.

National Center for Education Statistics. (2017). Repayment of student loans as of 2015 among 1995-96 and 2003-04 first-time beginning students: First look (NCES 2018-410). Washington, DC: National Center for Education Statistics.

National Conference of State Legislatures. (2016). Ballot measures database. Retrieved from http://www.ncsl. org

Nicholson, S. P. (2003). The political environment and ballot proposition awareness. American Journal of Political Science, 47(3), 403-410.

O'Brien, R. M., Stockard, J., \& Isaacson, L. (1999) The enduring effects of cohort characteristics on agespecific homicide rates, 1960-1995. American Journal of Sociology, 104(4), 1061-1095.

Plutzer, E. (2002). Becoming a habitual voter: Inertia, resources, and growth in young adulthood. American Political Science Review, 96(1), 41-56.

Putnam, R. D. (2000). Bowling alone: America's declining social capital. In L. Crothers \& C. Lockhart (Eds), Culture and politics. New York, NY: Palgrave Macmillan.

Li, Q., Pomantell, M. J., \& Schraufnagel, S. (2018). Cost of Voting in the American States. Election Law Journal: Rules, Politics, and Policy, 17(3), 234-247.
Robinson, R. V., \& Jackson, E. F. (2001). Is trust in others declining in America? An age-period-cohort analysis. Social Science Research, 30(1), 117-145.

Rouse, S. M., \& Ross, A. D. (2018). The politics of Millennials: Political beliefs and policy preferences of America's most diverse generation. Ann Arbor, MI: University of Michigan Press.

Ryder, N. B. (1965). The cohort as a concept in the study of social change. American Sociological Review, 30(6), 843-861.

Schlozman, D., \& Yohai, I. (2008). How initiatives don't always make citizens: Ballot initiatives in the American states, 1978-2004. Political Behavior, 30(4), 469-489.

Seabrook, N. R., Dyck, J. J., \& Lascher, E. L. (2015). Do ballot initiatives increase general political knowledge? Political Behavior, 37(2), 279-307.

Smith, M. (2001). The contingent effects of ballot initiatives and candidate races on turnout. American Journal of Political Science, 45(3), 700-706.

Smith, D. A., DeSantis, M., \& Kassel, J. (2006). Same-sex marriage ballot measures and the 2004 presidential election. State and Local Government Review, 38(2), 78-91.

The Campaign Finance Institute. (2019). Monetary competitiveness in gubernatorial elections, 2001-2016. Retrieved from http://www.cfinst.org

Taylor, P. (2016). The next America: Boomers, millennials, and the looming generational showdown. London: Hachette.

Taylor, P., \& Keeter, S. (2010). Millennials: A portrait of generation next (Pew Research Center report series). Washington, DC: Pew Research Center.

Tolbert, C. J., \& Smith, D. (2005). The educative effects of ballot initiatives on voter turnout. American Politics Research, 33(2), 283-309.

Tolbert, C. J., Bowen, D. C., \& Donovan, T. (2009). Initiative campaigns: Direct democracy and voter mobilization. American Politics Research, 37(1), 155-192.

Tolbert, C. J., Grummel, J. A., \& Smith, D. (2001). The effects of ballot initiatives on voter turnout in the American states. American Politics Research, 29(6), 625-648.

Tolbert, C. J., McNeal, R., \& Smith, D. (2003). Enhancing civic engagement: The effect of direct democracy on political participation and knowledge. State Politics \& Policy Quarterly, 3(1), 23-41.

U.S. Census Bureau. (2002-2016). Current population survey. Retrieved from www.census.gov

Wolfinger, R. E., \& Rosenstone, S. J. (1980). Who votes? (Vol. 22). New Haven, CT: Yale University Press. 


\section{About the Authors}

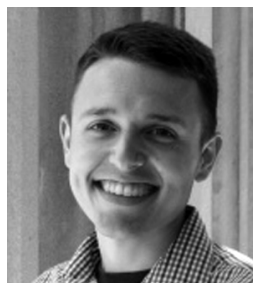

Scott J. LaCombe is a PhD candidate at the University of lowa. He specializes in the role of institutions in state politics, with an emphasis on the role of institutions in policy innovativeness and responsiveness. He also specializes in latent-variable and multi-level modeling to understand how institutional design moderates the relationship between public opinion and state policy.

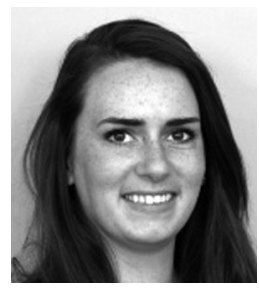

Courtney Juelich is a PhD candidate at the University of lowa. She focuses on the role of age-based generations in American politics, with a focus on the political behavior and attitudes of Millennials. 